of mathematics and physics, Mr. Ralli joined the technical staff of the Fairey Aviation Company in 1916.

From the beginning of his work there his outstanding ability was recognised. He carred out original research on the strength and performance of high-speed and high performance aircraft, which proved of the utmost value. He made a speciai study of the problems connected with airscrews, and it was largely due to his work that the Schneider Trophy was won from Italy in 1927 and retained in 1929. For his work on airscrew design he was awarded, in 1928, the Silver Medal of the Society.

All those who worked under Mr. Ralli, who was head of the Technical Department at Messrs. Fairey's, found his advice and experience placed ungrudgirgly at their disposal. Their loss is a loss to aviation as a whole of a man of great personal charm and ability.

\title{
Henry O'Neil de Hane Segrave, Associate
}

Major Sir Henry Segrave, who was only elected an Associate of the Society in May, was killed on Lake Windermere on $13^{\text {th }}$ June through the capsizing of the motor-boat Miss England II.

Born on 2and September, 1896 , Sir Henry was educated at Eton and Sandhurst. During the War he served in the and Warwickshire Regiment and then in the Royal Flying Corps. After much service he became disabled as the result of a crash and was posted to the War Office in 1917, and in May, 1918, was appointed Technical Secretary to the Minister for Air. He went to Washington with the British Aviation Mission in the same year.

After the War Sir Henry turned his attention to motor-car racing, and first achieved international fame in 1923 by winning the Grand Prix de France. He won miny other important Continental races during the next few years, and achieved several successes at Brooklands. At Daytona Beach, Florida, in 1926, Sir Henry achieved a world record motor-car speed of 203.988 m.p.h., and his last and greatest triumph in road racing was in March, 1929, when he broke the world record at Daytona in the "Golden Arrow" at an average speed of $33^{1.36}$ m.p.h.

Sir Henry then turned his attention to obtaining the water-speed record for Great Britain, in the achievement of which he met his death.

\section{Captain Charles Sutton, Associate Member}

Captain Charles Sutton, who was killed in a flying accident to the seaplane he was piloting at Toronto in September, was born on August $7^{\text {th }}$, 1894. Edurated at. Clacton, he joined $C$. A. Vandervell's and received training in machineshop work and particularly electrical work.

He joined the R.F.C. in 19I6, and took various engine courses, as well as the pilct's course at the Central Flying School. Captain Sutton had a wide experience of various types of aircraft, from the early Maurice Farman's to the latest type of post-war aircraft. After service on the Western Front he was drafted home in command of detached flights against air raiders. After the War he saw service in Iraq, Egypt and the Sudan, until I926 when he went to Canada and took part in air survey exploration work. He had some 2,000 solo flying hours to his credit and an experience of flying under all conditions which has been given to comparatively few. Captain Sutton became an Associate Membe of the Society in 1926, and was keenly interested in its work. An enthusiast in all he did he will be missed by all those who knew him well, and knew how much his heart was in aviation. 